\title{
Using near-infrared spectroscopy to discriminate closely related species: A case study of neotropical ferns
}

\author{
Darlem Nikerlly Amaral Paiva ${ }^{1,3}$, Ricardo de Oliveira Perdiz ${ }^{2}$, and Thaís Elias Almeida ${ }^{1}$
}

${ }^{1}$ Universidade Federal do Oeste do Pará, Programa de Pós-graduação em Biodiversidade, Rua Vera Paz, s/n (Unidade Tapajós) Bairro Salé, 68040-255, Santarém, PA, Brazil;

${ }^{2}$ Instituto Nacional de Pesquisas da Amazônia, Programa de Pós-graduação em Ciências Biológicas, Avenida André Araújo, 2936, Manaus, AM, 69060-001, Brazil.

${ }^{3}$ Author for correspondence

Email address: DNAP: nikerllyjc@hotmail.com

ROP: ricoperdiz@gmail.com

TEA: blotiella@gmail.com, ORCID: 0000-0002-1611-1333

\begin{abstract}
Identifying plant species requires considerable knowledge and can be difficult without complete specimens. Fourier-transform near-infrared spectroscopy (FT-NIR) is an effective technique for discriminating plant species, especially angiosperms. However, its efficacy has never been tested on ferns. Here we tested the accuracy of FT-NIR at discriminating species of the genus Microgramma. We obtained 16 spectral readings per individual from the adaxial and abaxial surfaces of 100 specimens belonging to 13 species. The analyses included all 1557 spectral variables. We tested different datasets (adaxial+abaxial, adaxial, and abaxial) to compare the correct identification of species through the construction of discriminant models (LDA, PLS) and cross-validation techniques (leave-one-out, K-fold). All analyses recovered an overall high percentage $(>90 \%)$ of correct predictions of specimen identifications for all datasets, regardless of the model or cross-validation used. On average, there was $>95 \%$ accuracy when using PLSDA and both cross-validations. Our results show the high predictive power of FT-NIR at correctly discriminating fern species when using leaves of dried herbarium specimens. The technique is sensitive enough to reflect species delimitation problems and possible hybridization, and it has the potential of helping better delimit and identify fern species.
\end{abstract}

Key words: barcoding; discrimination of plant species; FT-NIR; integrative taxonomy; metabolomics; Microgramma. 
bioRxiv preprint doi: https://doi.org/10.1101/2020.10.19.343947; this version posted October 19, 2020. The copyright holder for this preprint (which was not certified by peer review) is the author/funder, who has granted bioRxiv a license to display the preprint in perpetuity. It is made available under aCC-BY-NC-ND 4.0 International license.

Paiva et al. - Use of NIR on fern systematics

\section{INTRODUCTION}

Defining and identifying species using qualitative morphological traits can be challenging even though species identification is fundamental to some areas of science and sustainable dynamics (Galtier 2018; Pinheiro et al. 2018). Correct identifications also contribute significantly to understanding the evolutionary history of many species and the diversity of biological groups in rich and threatened areas, such as tropical forests (Costello 2015). Considering the biological and historical diversity of polymorphisms in plants, allied with centuries of describing species using alpha taxonomy tools, the correct identification of a specimen requires experts with considerable knowledge (Ahrends et al. 2011; Lacerda and Nimmo 2010; Richard and Evans 2006).

A problem when identifying plant species is the absence of complete specimens, including both sterile and fertile material, such as flowers or fruits of seed plants (Gomes et al. 2013). Difficult to access and insufficient or unrepresentative collections of species widely distributed in highly diverse areas can also pose a problem when identifying specimens (Lacerda and Nimmo 2010). Among the traditional identification methods used for plants, keys stand out and are widely employed (Smith 2017). However, polymorphisms and the complexity of shapes, associated with homoplasies and cryptic taxa, for example, create the need for more elaborate tools aimed primarily at the identification, conservation, and elucidation of unclear relationships of plants (Durgante et al. 2013; Pinheiro et al. 2018).

In addition to the use of macromorphology, DNA barcoding is an internationally recognized tool and widely used in species identification, ecological studies, and forensic analyses ( $\mathrm{Li}$ et al. 2015; Shokralla et al. 2014). In studies of animal groups that used this molecular approach, the technique proved to be highly efficient (e.g., Ohira et al. 2018; Porco et al. 2012; Pérez-Losada et al. 2012). Using DNA barcoding has been less successful at identifying plants compared to animals (Li et al. 2015). According to Fazekas et al. (2012), this is partially due to hybridization, polyploidy, and speciation related to reproductive systems. However, these are not problems common to all plant groups; the success in using DNA barcoding is lineage-dependent ( $\mathrm{Li}$ et al. 2015). Identifying herbarium specimens using this method is also more difficult compared to fresh material, since dried specimens require a greater combination of primers that increases the chances of incorrect sequencing ( $\mathrm{Li}$ et al. 2015; Vere et al. 2012). Furthermore, the widespread use of this technique is still limited because of the high cost (Stein et al. 2014).

Alternatively, one of the most promising tools currently used in botanical identification is Fourier-transform near-infrared spectroscopy (FT-NIR) (e.g., Lang et al. 2017; Rodríguez- 
bioRxiv preprint doi: https://doi.org/10.1101/2020.10.19.343947; this version posted October 19, 2020. The copyright holder for this preprint (which was not certified by peer review) is the author/funder, who has granted bioRxiv a license to display the preprint in perpetuity. It is made available under aCC-BY-NC-ND 4.0 International license.

Paiva et al. - Use of NIR on fern systematics

Fernandez et al. 2011). The principle of the technique is to irradiate fractions of biological material (e.g., a dry leaf) in the infrared region. As a result, a set of absorbance values at different wavelengths (the spectra) is defined for the material (Workman and Weyer 2007). The spectra reflect molecular bonds, such as $\mathrm{C}-\mathrm{H}, \mathrm{N}-\mathrm{H}, \mathrm{S}-\mathrm{H}$ or $\mathrm{O}-\mathrm{H}$, and are therefore related to biological molecules and the metabolome of the irradiated tissue (Stuart 2005).

Research using near-infrared spectroscopy to discriminate plant species is gaining more and more attention in plant taxonomy, especially for angiosperms (Durgante et al. 2013; Kim et al. 2004; Krajšek et al. 2008; Lang et al. 2017). The tool has been shown to be more practical and accurate than genetic or morphological methods (Castillo et al. 2008), is capable of consistently discriminating phylogenetic relationships of flowering plant species (Kim et al. 2004), and has been used in different works to aid in species circumscription and identification of several plant groups (Damasco et al. 2019; Durgante et al. 2013; Lang et al. 2017; Prata et al. 2018; Shen et al. 2020). However, the technique has not been tested to identify other groups of embryophytes, such as ferns and lycophytes, or bryophytes. (Guzmán et al. 2020).

Ferns are the second most diverse group of vascular plants, occur from tundras to tropical forests, and occupy niches from the ground to the canopy (Moran 2008). Due to the absence of flowers, fruits, and seeds, fern identification relies mainly on rhizome, frond, and sorus morphology (Schoute 1938). Sporophyte characters such as indument (trichomes and scales), leaf shape, and the structure and arrangement of sori are fundamental elements in the differentiation between species (Christenhusz and Chase 2014; Schoute 1938).

Microgramma (Polypodiaceae) comprises ca. 30 species, occurs in the Neotropics and tropical Africa (Almeida 2014), and is monophyletic according to the most recent circumscriptions (Salino et al. 2008; Almeida et al. in press). The genus exhibits wide morphological variation, especially in the leaves (e.g., it has both monomorphic and dimorphic species), leaf indument, and sorus arrangement (Almeida 2014). Additionally, intraspecific phenotypic variation and interspecific morphological overlap are found in closely related species, and there are species complexes, which may result in misidentifications in the genus (Almeida et al. in press). Using Microgramma as a model, our goal was to test the effectiveness of Fourier-transform near-infrared spectroscopy (FT-NIR) at discriminating and identifying closely related species in the fern lineage.

\section{METHODS}

Sampling-Dried leaves were selected from specimens at the BHCB, HSTM, and INPA herbaria (acronyms according to Thiers 2020 onwards: http://sweetgum.nybg.org/science/ih/). 
bioRxiv preprint doi: https://doi.org/10.1101/2020.10.19.343947; this version posted October 19, 2020. The copyright holder for this preprint (which was not certified by peer review) is the author/funder, who has granted bioRxiv a license to display the preprint in perpetuity. It is made available under aCC-BY-NC-ND 4.0 International license.

Paiva et al. - Use of NIR on fern systematics

One hundred specimens belonging to thirteen species of Microgramma were analyzed (Appendix): M. baldwinii Brade, M. crispata (Fée) R.M.Tryon \& A.F.Tryon, M. dictyophylla (Kunze ex Mett.) de la Sota, M. geminata (Schrad.) R.M.Tryon \& A.F.Tryon, M. lindbergii (Mett. ex Kuhn) de la Sota, M. lycopodioides (L.) Copel., M. megalophylla (Desv.) de la Sota, M. percussa (Cav.) de la Sota, M. persicariifolia (Schrad.) C.Presl, M. reptans (Cav.) A.R.Sm., M. squamulosa (Kaulf.) de la Sota, M. thurnii (Baker) R.M.Tryon \& Stolze, and M. vacciniifolia (Langsd. \& Fisch.) Copel. All specimens had their identification confirmed by an expert (senior author). Only species with a minimum of five available specimens, with both fertile and sterile leaves, were selected. When possible, samples with fronds that were very damaged by insects or with signs of fungi or other epiphilic organisms were avoided. Sixteen spectral readings were obtained for each specimen (when possible), which included four readings, two on the adaxial surface and two on the abaxial surface, of four different leaves. No distinction between fertile and sterile leaves was made. The acquisition of the spectra lasted 30 seconds per reading and was taken using a Thermo Nicollet spectrophotometer, FT-NIR Antaris II Method Development System (MDS). The spectral readings consisted of 1,557 leaf absorbance values in the region of 4,000 to $10,000 \mathrm{~cm}-1$ (1000 to $2500 \mathrm{~nm}$ ). Each measurement produced by the equipment was an average of 16 readings with a wavelength resolution of $8 \mathrm{~cm}-1$. The equipment was calibrated every 4 hours of use. A black body was placed over the frond to prevent light scattering.

Analyses-All analyses were implemented in the statistical program R version 4.0.2 (R Core Team 2020). Three datasets using all FT-NIR spectrum wavelengths were tested to construct the spectral models: data of (i) adaxial+abaxial surfaces, (ii) adaxial surface only, and (iii) abaxial surface only. The datasets were explored using a principal component analysis (PCA). This technique allows the visualization of data of a smaller set of variables but still preserves the maximum information from the original variable set (Hongyu et al. 2016), thus allowing an exploratory analysis of the behavior of the spectra. The results of the PCA were represented in two-dimensional graphs using the first two main components with higher variation in the data.

To predict species based on spectral data, we used two supervised pattern recognition techniques: linear discriminant analysis (LDA) and partial least squares discriminant analysis (PLS-DA) (Berrueta and Héberger 2007). The LDA is a technique that discriminates and classifies objects based on previously defined groups (Sharma and Paliwal 2015), where the dependent variables corresponded to the species (categories) and the independent variables 
bioRxiv preprint doi: https://doi.org/10.1101/2020.10.19.343947; this version posted October 19, 2020. The copyright holder for this preprint (which was not certified by peer review) is the author/funder, who has granted bioRxiv a license to display the preprint in perpetuity. It is made available under aCC-BY-NC-ND 4.0 International license.

Paiva et al. - Use of NIR on fern systematics

represent the absorbance values in the near-infrared. The PLS-DA, which also classifies the samples according to defined categories, is based on finding components that better explain the variations of the variables between classes, giving less weight to the noise and uncorrelated variations (Mevik and Cederkvist 2004). Both models were tested using the three different datasets.

Cross-validation techniques were used to assess model performance and species discrimination. The K-fold validation technique (Burman 1989) is where the set of calibration samples is divided into $\mathrm{K}$ subsets, with a subset taken out for validation and the remaining $\mathrm{K}-1$ subsets used to build the model. Thus, at the end of K steps, the data is used in both test subsets and validation (Yadav et al. 2016). Here we use $K=10$, described as the value that presents the best performance in the sampling, with the least bias in the error rate estimates (Kohavi 1995).

The leave-one-out (LOO) technique uses k-1 samples to generate the discriminant function and the sample not included in the model serves to validate it, obtaining the percentage of the model's prediction (Kohavi 1995). Thus, we compared the predictions of individual identities for each species in each of the datasets.

\section{RESULTS}

We found considerable variation in the near-infrared spectral data among the sampled species (Fig. 1). Among the three datasets tested, the adaxial+abaxial (i) dataset showed 97.8 $\%$ of the spectral variation, the adaxial (ii) dataset showed $97.6 \%$ of the spectral variation, and the abaxial (iii) dataset was the most representative with a spectral variation of $98.1 \%$ (Fig. 2). For the abaxial (iii) dataset, individuals belonging to the same species tended to group more cohesively and consequently less mixed compared to the remaining two datasets (adaxial+abaxial [i] and adaxial [ii]) (Fig. 2).

All datasets had high predictive results in the identification of species (correct predictions higher than $90 \%$ ) for both models (PLS and LDA) and validation techniques (Kfold and LOO) (Table 1). Among the best percentages for plant discrimination (over $96 \%$ ) were the LDA model with the (iii) abaxial dataset for both the K-fold and leave-one-out validation techniques, and the PLS-DA model with the (i) adaxial+abaxial dataset and leaveone-out validation. 
Table 1 - Average percentage of correct identifications using a discriminant analysis and all of the FTNIR spectrum wavelength data (1000-2500 nm) for the three datasets, (i) adaxial+abaxial leaf surfaces, (ii) adaxial surface only and (iii) abaxial surface only, for both models (LDA = linear discriminant analysis, PLS-DA = partial least squares discriminant analysis) and validation tests ( $K$-fold and leaveone-out).

\begin{tabular}{ccccc}
\hline & \multicolumn{2}{c}{ LDA } & \multicolumn{2}{c}{ PLS-DA } \\
\hline Dataset & K-fold & LOO & K-fold & LOO \\
Adaxial+abaxial & 95.3 & 93.0 & 96.2 & 96.7 \\
Adaxial & 95.4 & 95.8 & 93.9 & 94.3 \\
Abaxial & 96.2 & 96.2 & 94.6 & 95.1 \\
\hline
\end{tabular}

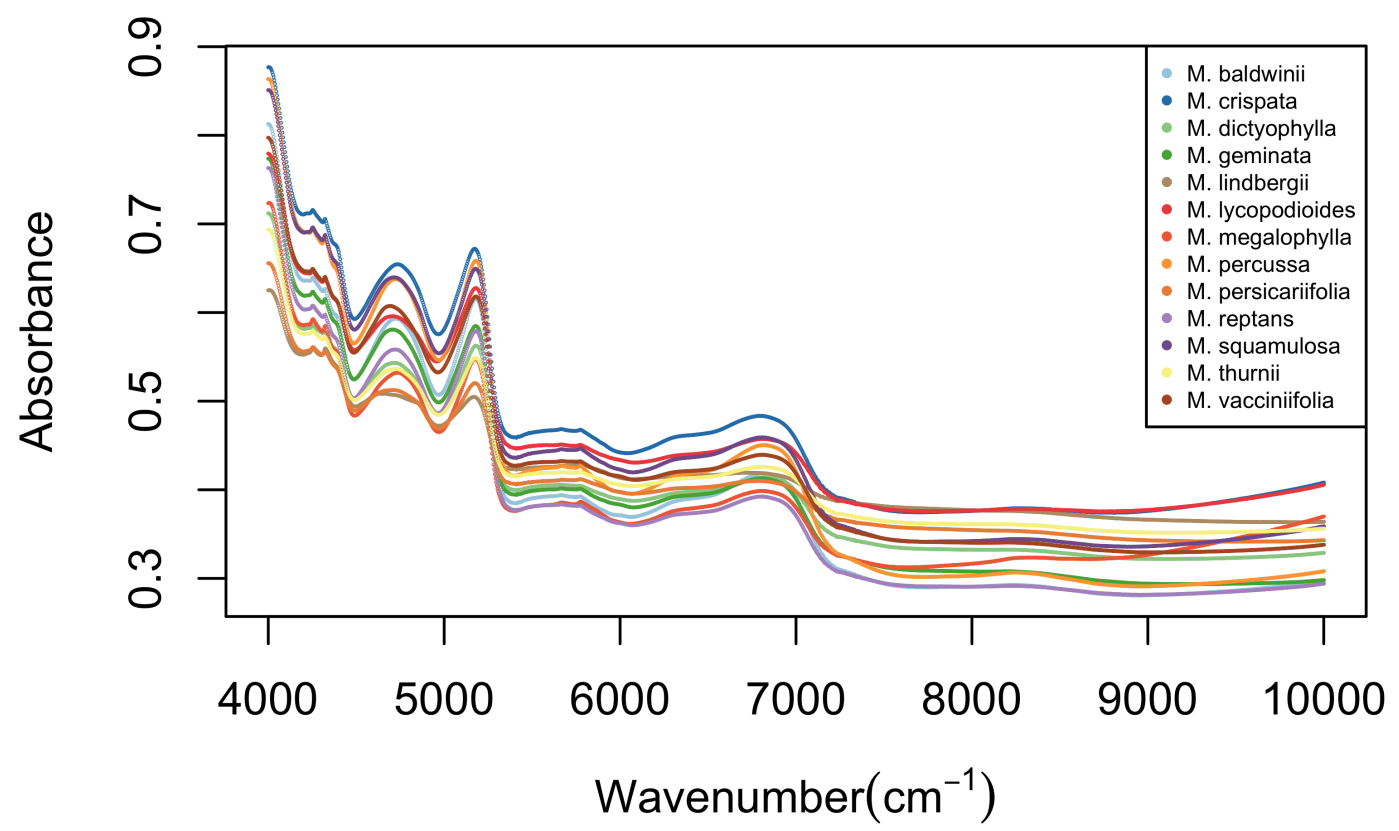

Figure 1 - Average near-infrared spectral data for the thirteen sampled Microgramma species.

The adaxial+abaxial (i) dataset alone had the best percentage only for the PLS model and leave-one-out validation (96.7 \%), and both validations in a similar way resulted in elevated correct identifications for the three datasets tested (adaxial+abaxial, adaxial, abaxial).

All individuals of M. crispata and M. megalophylla were $100 \%$ correctly predicted in both models and validations tests, with no confusion of readings with any sample related to any other species (Figs 3, 4). For six species, M. dictyophylla, M. geminata, M. lindbergii, $M$. lycopodioides, M. percussa, and M. reptans, the correct prediction of the identities of individuals in all models and validations ranged from 90 to $100 \%$ (Figs. 3, 4). 
bioRxiv preprint doi: https://doi.org/10.1101/2020.10.19.343947; this version posted October 19,2020 . The copyright holder for this preprint (which was not certified by peer review) is the author/funder, who has granted bioRxiv a license to display the preprint in perpetuity. It is made available under aCC-BY-NC-ND 4.0 International license.

Paiva et al. - Use of NIR on fern systematics

Two species (15.3\%), M. persicariifolia and M. squamulosa, had correct predictions between 80 and $100 \%$ among the models and validations tests (Figs. 3, 4). For M. baldwinii, the abaxial (iii) dataset underperformed in both the LDA and PLS-DA models and validations (Figs. 3, 4). Additionally, in the PLS-DA model for this species, the adaxial+abaxial (i) dataset had $88 \%$ and $81 \%$ correct predictions for the K-fold and LOO validations, respectively. The remaining models and validations recovered $100 \%$ correct predictions. For M. persicariifolia, the lowest prediction value ( $83 \%$ ) was found in the PLS model for the abaxial dataset, for both validations; the remaining models and validations recovered $100 \%$ correct predictions. Regarding M. squamulosa, only the abaxial (iii) dataset had $100 \%$ correct predictions in both models and validations (Figs. 3, 4).

The two species with the lowest percentages of correct predictions were M. thurnii and M. vacciniifolia. For M. thurnii, of the 12 different combinations of the datasets and tests, only two recovered one of the lowest percentages of correct predictions (75\%): the PLS model, with the adaxial (ii) dataset, for both validations. Four tests recovered more than $90 \%$ correct predictions, and six had $100 \%$ correct identifications (Figs. 3, 4). For this species, the PLS-DA models underperformed compared to the LDA models.

Microgramma vacciniifolia was the species with the lowest percentage of correct predictions (73\%), which was found by the PLS model with the adaxial+abaxial and adaxial datasets; although, for the abaxial dataset there was $100 \%$ accuracy in the identifications (data not shown). Prediction errors for $M$. vacciniifolia individuals occurred mainly with spectra associated with M. geminata and M. squamulosa in both models. Even so, the lowest percentage observed was $73 \%$ in the PLS model (Fig. 4).

\section{DISCUSSION}

This is the first time that Fourier-transform near-infrared spectroscopy (FT-NIR) was tested for discriminating ferns species. Our results show that FT-NIR is a powerful tool that can be easily applied to species identification using spectral data of leaves. For all different scenarios tested (species, datasets, models, and validations), more than $85 \%$ had an accuracy equal or greater than $90 \%$ (Figs. 3, 4), with an average above $93 \%$ (Table 1).

Regarding the accuracy of FT-NIR at species identification, we recognize the importance of using well-defined species circumscriptions and well-identified samples for constructing spectral models. In this work, when incorrectly identified specimens were used for the control group (an individual of M. reptans incorrectly determined as M. baldwinii), the 
bioRxiv preprint doi: https://doi.org/10.1101/2020.10.19.343947; this version posted October 19, 2020. The copyright holder for this preprint (which was not certified by peer review) is the author/funder, who has granted bioRxiv a license to display the preprint in perpetuity. It is made available under aCC-BY-NC-ND 4.0 International license.

Paiva et al. - Use of NIR on fern systematics
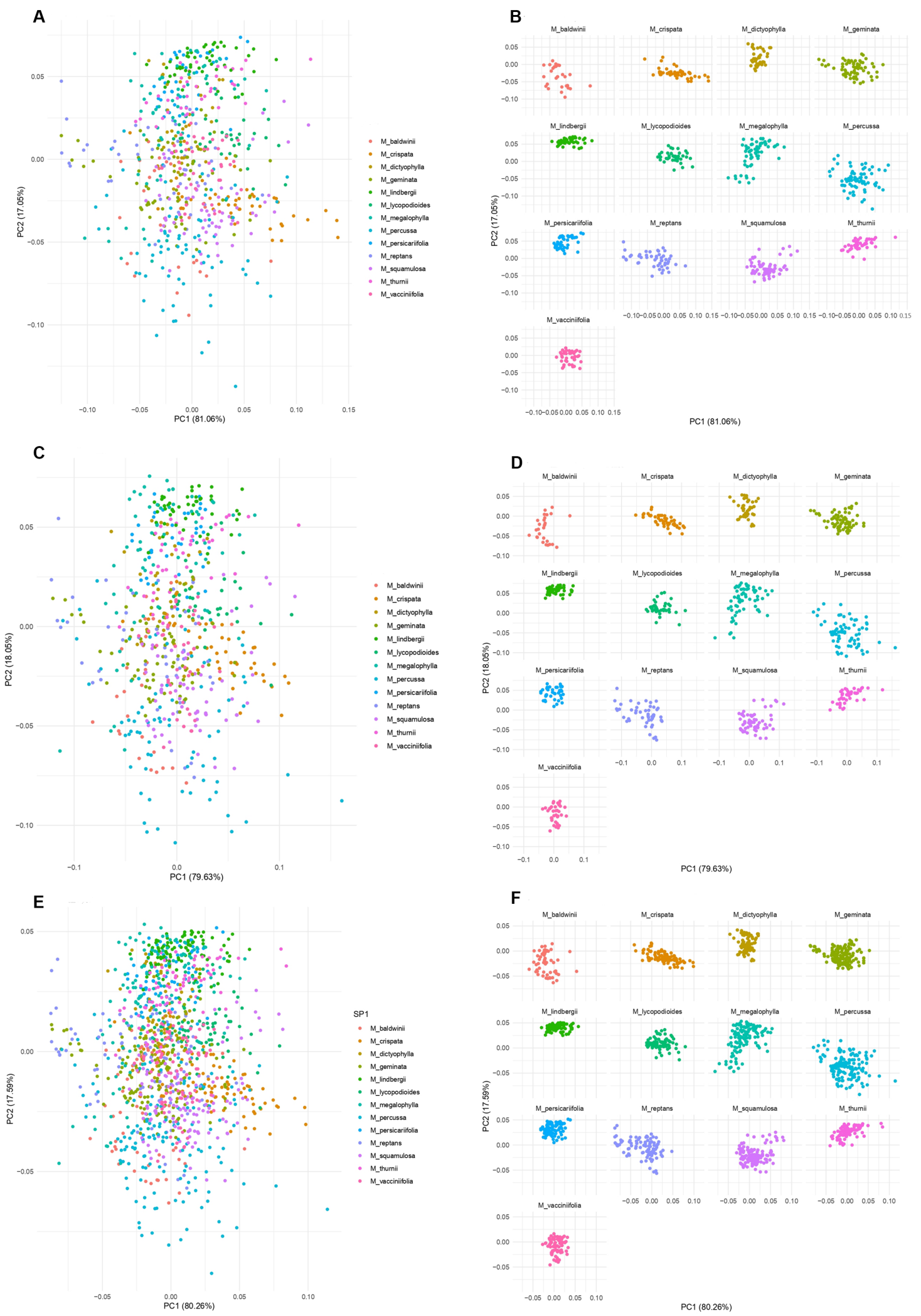

Figure 2 - Principal component analysis (PCA) plot of the first two principal component axes for spectral data. A. Abaxial surface dataset (iii), all species. B. Abaxial surface dataset (iii), individually represented species. $\boldsymbol{C}$. Adaxial surface dataset (ii), all species. D. Adaxial surface dataset (ii), individually represented species. $\boldsymbol{E}$. Adaxial+abaxial surface dataset (i), all species. $\boldsymbol{F}$. Adaxial +abaxial surface dataset (i), individually represented species. 
bioRxiv preprint doi: https://doi.org/10.1101/2020.10.19.343947; this version posted October 19, 2020. The copyright holder for this preprint (which was not certified by peer review) is the author/funder, who has granted bioRxiv a license to display the preprint in perpetuity. It is made available under aCC-BY-NC-ND 4.0 International license.

Paiva et al. - Use of NIR on fern systematics

A

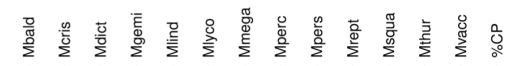

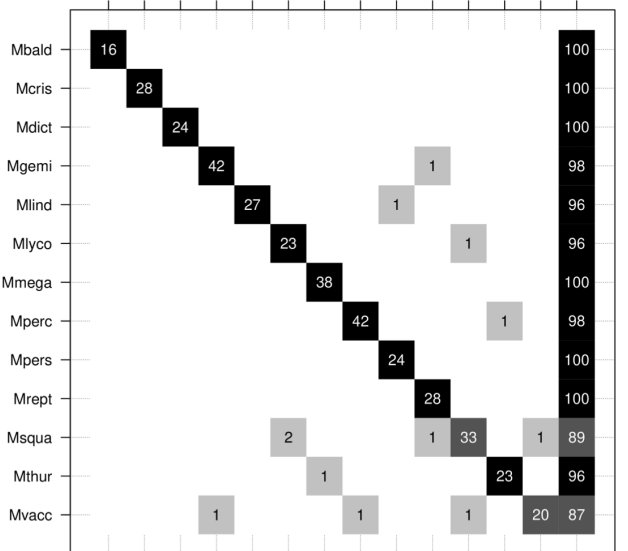

C
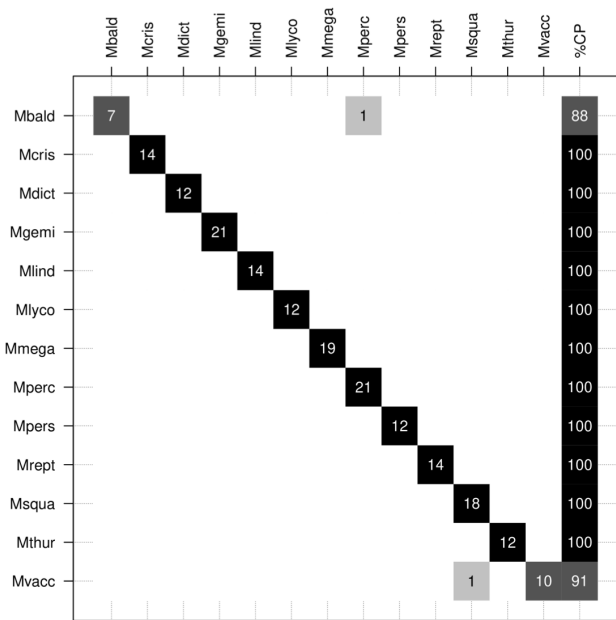

$\mathrm{E}$
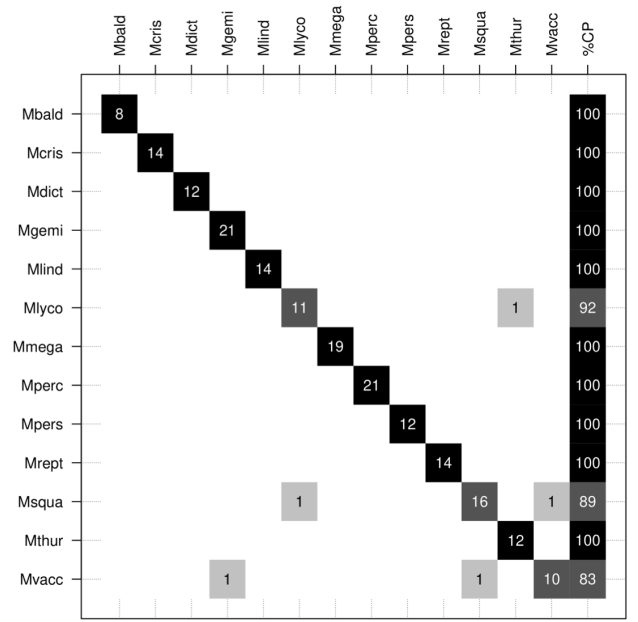

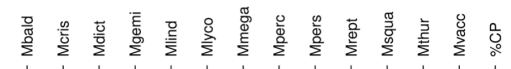

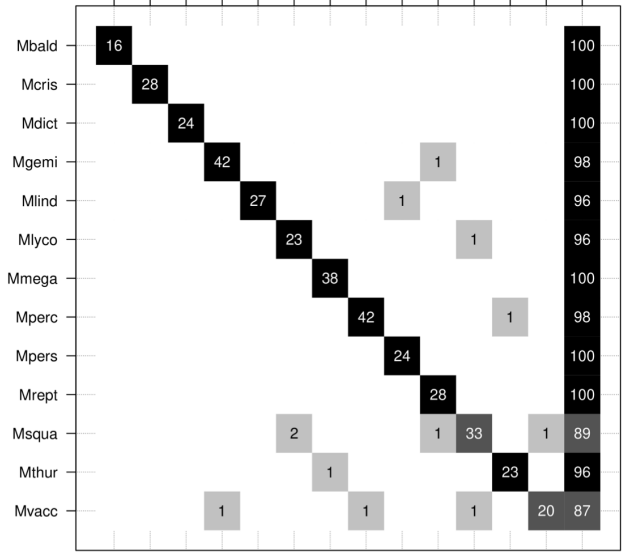

D

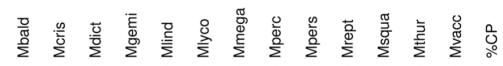

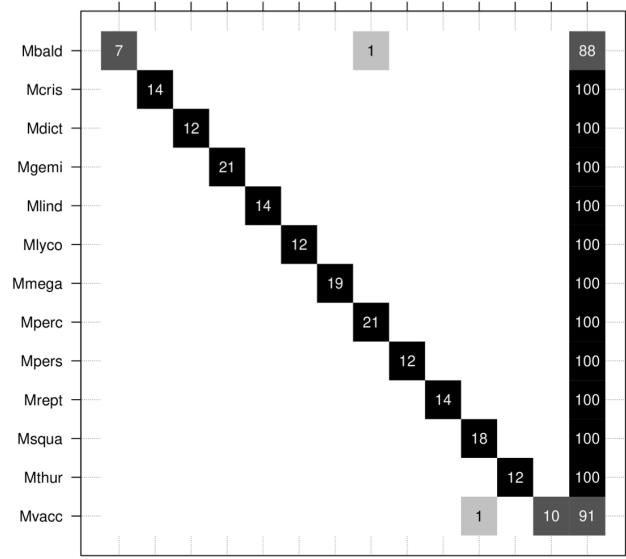

F
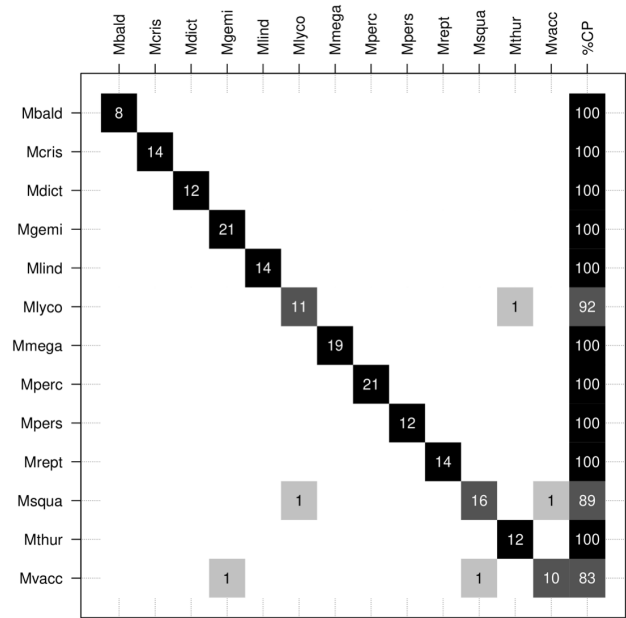

Figure 3 - Confusion matrices resulting from the linear discriminant analysis (LDA) for the LOO and K-fold validations. (A) LOO validation, adaxial+abaxial surface data; (B) K-fold validation, adaxial+abaxial surface data; (C) LOO validation, abaxial surface data only; (D) K-fold validation, abaxial surface data only; (E) LOO validation, adaxial surface data only; (F) K-fold validation, adaxial surface data only. The names of the species observed are in rows and columns. The values on the diagonal correspond to correct predictions and those outside the diagonal correspond to incorrect predictions. Abbreviations: . bald = M. baldwinii; M. cris = M. crispata; $M$. dict $=$ M. dictyophylla; $M$. gemi = M. geminata; $M$. lind = M. lindbergii; $M$. lyco = M. lycopodioides; $M$. 
bioRxiv preprint doi: https://doi.org/10.1101/2020.10.19.343947; this version posted October 19, 2020. The copyright holder for this preprint (which was not certified by peer review) is the author/funder, who has granted bioRxiv a license to display the preprint in perpetuity. It is made available under aCC-BY-NC-ND 4.0 International license.

Paiva et al. - Use of NIR on fern systematics

$m e g a=$ M. megalophylla; $M$. perc $=$ M. percussa; $M$. pers $=$ M. persicariifolia; M.rept $=$ M. reptans; $M$. squa $=$ M. squamulosa; $M$. thur $=$ M. thurnii; $M$. vacc $=$ M. vacciniifolia .

accuracy decreased to $85.5 \%$, and after redoing the analysis with the correct identification, the correct prediction of the individuals of M. baldwinii reached $93.4 \%$.

The chemical composition and other structural characteristics of leaves vary within and between species, as a result of the developmental stage and a combination of environmental factors, ontogeny, and composition of the plant epidermis (Mediavilla et al. 2014). Ferns are characterized by the presence of sori, which are usually on the abaxial surface of the fronds (Schoute 1938). Some lineages exhibit leaf dimorphism, with leaves morphologically and physiologically specialized for photosynthesis or reproduction, and in some cases, there are extreme differences between both types (Wagner and Wagner 1977). In our study, we used species that are both monomorphic (M. baldwinii, M. dictyophylla, M. geminata, M. lindbergii, M. lycopodioides, M. megalophylla, M. percussa, M. persicariifolia, and M. thurnii) and dimorphic (M. crispata, M. reptans, M. squamulosa, and M. vacciniifolia). The dataset for the abaxial leaf surface, which can be more affected by the presence of sori, had (on average) higher percentages of discriminating samples than the other tested datasets (Table 1). Given our results, we believe the presence of sori has minimal influence on the spectral readings and subsequent discrimination power among species. However, this can vary among different lineages, and further tests controlling for fertile and sterile frond spectral readings are recommended.

One of the species that was more difficult to discriminate was M. vacciniifolia, where ca. $40 \%$ of the samples were incorrectly predicted as M. squamulosa. These species are sympatric in eastern and central Brazil and exhibit wide morphological variation (Almeida 2014). Our results using near-infrared spectroscopy (NIR) could be revealing inconsistencies in their current taxonomic circumscriptions. Also, the existence of hybrids between these species (Sota 1973) might explain the related spectral readings and the lower percentage of correct predictions. The technique has been shown to detect differences in the physical and biochemical compositions expressed in plant samples, even between closely related species, populations, and hybrids (Atkinson et al. 1997; Cui et al. 2012; Humphreys et al. 2008). 
bioRxiv preprint doi: https://doi.org/10.1101/2020.10.19.343947; this version posted October 19, 2020. The copyright holder for this preprint (which was not certified by peer review) is the author/funder, who has granted bioRxiv a license to display the preprint in perpetuity. It is made available under aCC-BY-NC-ND 4.0 International license.

Paiva et al. - Use of NIR on fern systematics

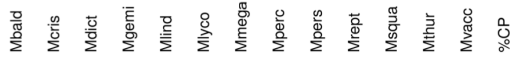

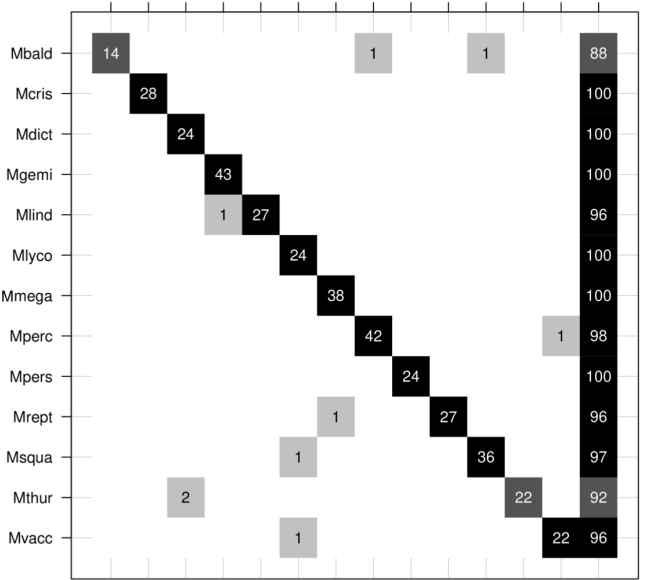

C
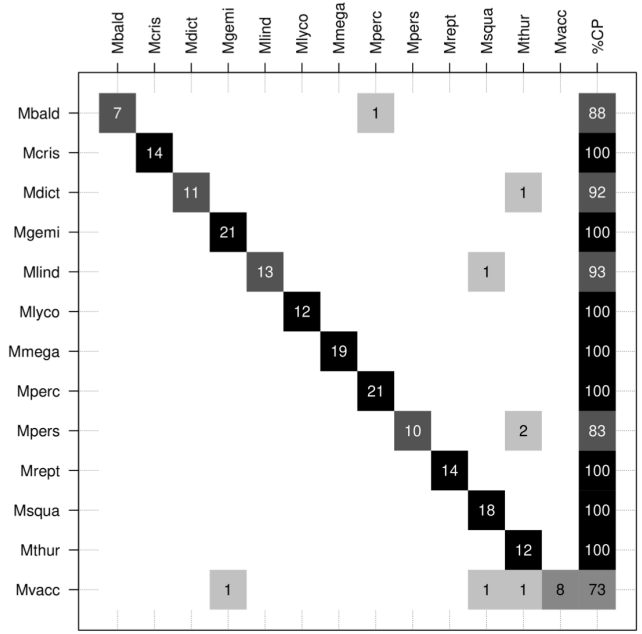

$E$
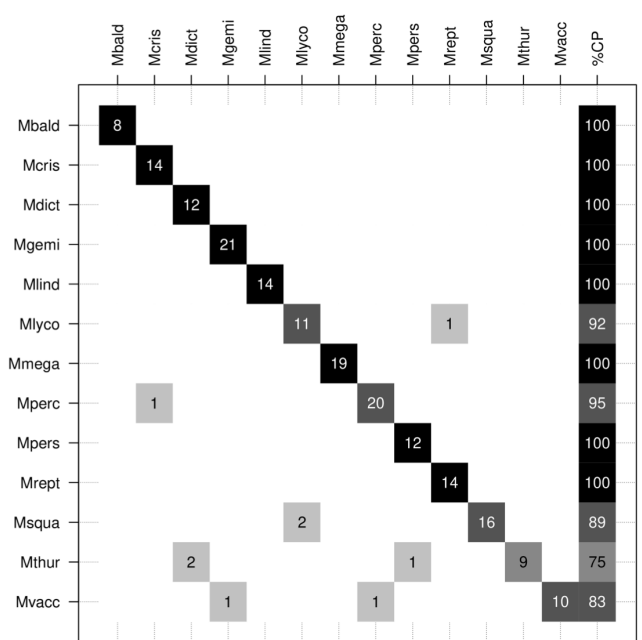

B

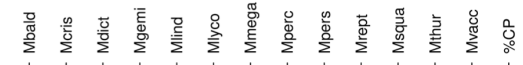

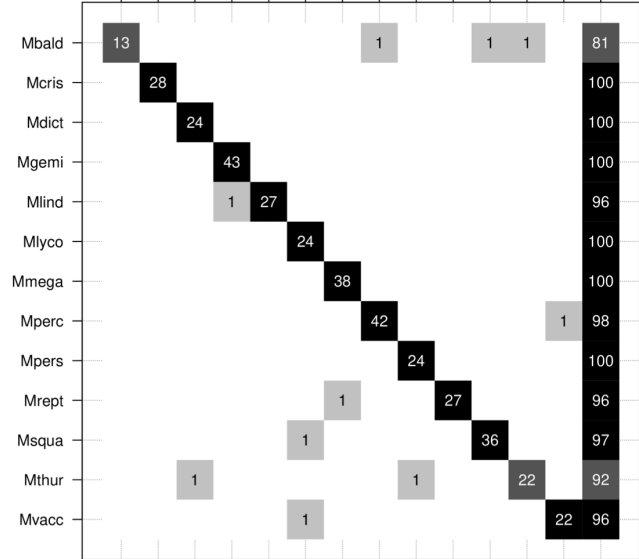

D
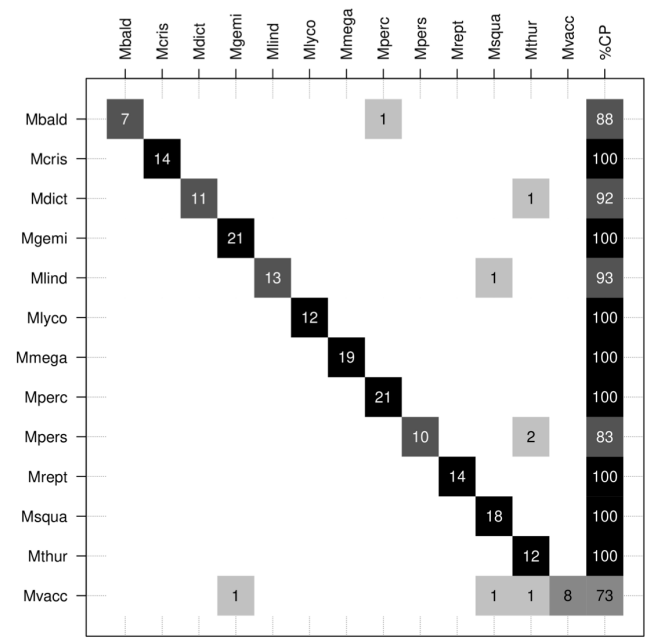

$\mathrm{F}$

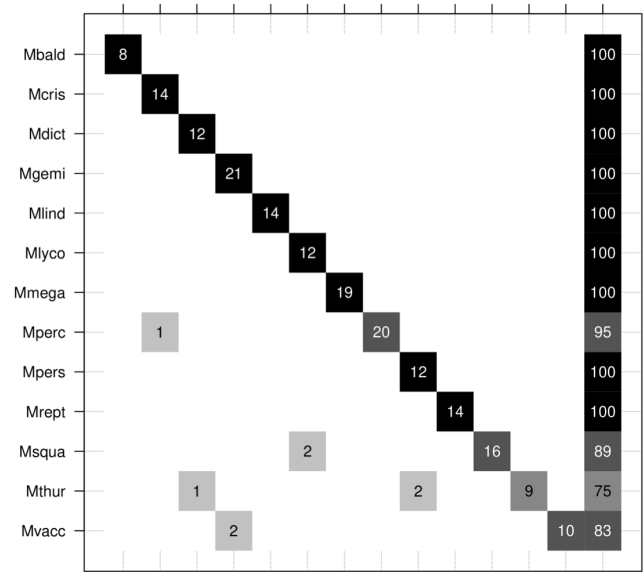

Figure 4 - (A) K-fold validation, adaxial+abaxial surface data; (B) LOO validation, adaxial+abaxial surface data; (C) LOO validation, abaxial surface data only; (D) K-fold validation, abaxial surface data only; (E) K-fold validation, adaxial surface data only; (F) LOO validation, adaxial surface data only. The names of the species observed are in rows and columns. The values on the diagonal correspond to correct predictions and those outside the diagonal correspond to incorrect predictions. Abbreviations: . bald = M. baldwinii; $M$. cris = M. crispata; $M$. dict $=$ M. dictyophylla; $M$. gemi = M. geminata; $M$. lind = M. lindbergii; $M$. lyco = M. lycopodioides; $M$. 
bioRxiv preprint doi: https://doi.org/10.1101/2020.10.19.343947; this version posted October 19, 2020. The copyright holder for this preprint (which was not certified by peer review) is the author/funder, who has granted bioRxiv a license to display the preprint in perpetuity. It is made available under aCC-BY-NC-ND 4.0 International license.

Paiva et al. - Use of NIR on fern systematics

$m e g a=$ M. megalophylla; $M$. perc $=$ M. percussa; $M$. pers $=$ M. persicariifolia; M.rept $=$ M. reptans; $M$. squa $=$ M. squamulosa; $M$. thur $=$ M. thurnii; $M$. vacc $=$ M. vacciniifolia.

Our best results show that the best models and validations can, on average, correctly predict the identification of species $96.7 \%$ of the time when using all wavelengths to construct the models, which is comparable to previously published taxonomic works. Prata et al. (2018) demonstrated for the first time that near-infrared spectroscopy on leaves of subspecies of the Pagamea guianensis complex can discriminate taxa with high precision. Fan et al. (2010) tested and proved the reliability of the technique at discriminating Ephedra plants from different habitats and collection seasons, while Lang et al. (2017) showed the effectiveness of the technique at discriminating species, genera, and families of tree species from eighteen different angiosperm families. For groups of closely related plants, the technique has shown excellent results for species of Protium (Burseraceae), confirming the differences in spectral signatures among species (Damasco et al. 2019).

The high predictive power of FT-NIR at discriminating fern species, presented here, is superior to that observed for this lineage using a single region of two combined DNA barcodes, for which the best performance was $75 \%$ correct predictions (Li et al. 2011; Wang et al. 2016). Identifying ferns and other plant groups using DNA barcoding is also an expensive technique and different lineages require specific combinations of molecular markers, which can make this technique complicated ( $\mathrm{Li}$ et al. 2011; Lima et al. 2018). However, barcoding gametophytes has shown promising results for identifying species of ferns, which represents a great contribution to what is known about the evolution of this group (Schneider and Schuettpelz 2006). Our work does not intend to minimize the importance of other techniques used in plant systematics, but rather tested the reliability and effectiveness of FT-NIR at discriminating species in a group known to be problematic. Further, it highlights the potential of using this method in studies about plant systematics.

\section{CONCLUSION}

Our results show that near-infrared spectroscopy (NIR) is a highly effective, costeffective, and non-destructive technique that can be used to discriminate closely related species. In addition to the possibility of obtaining spectral data quickly with minimal damage to samples, the technique provides greater reliability at discriminating morphologically similar fern species, as previously found for some angiosperms. The accuracy of the identifications is comparable 
bioRxiv preprint doi: https://doi.org/10.1101/2020.10.19.343947; this version posted October 19, 2020. The copyright holder for this preprint (which was not certified by peer review) is the author/funder, who has granted bioRxiv a license to display the preprint in perpetuity. It is made available under aCC-BY-NC-ND 4.0 International license.

Paiva et al. - Use of NIR on fern systematics

to and even surpasses that of DNA barcoding, even for species from highly diverse and heterogeneous areas, such as tropical forests. We believe that NIR has great potential to be used in integrative taxonomic studies that aim to better understand species circumscriptions in the fern lineage.

\section{ACKNOWLEDGMENTS}

This study was partly financed by the Coordenação de Aperfeiçoamento de Pessoal de Nível Superior - Brasil (CAPES) - financing code 001, and Programa Nacional de Cooperação Acadêmica na Amazônia (PROCAD-AM/CAPES 21/2018, nº 88887.200472/2018-00). The authors thank the following: B. Leal, L.L. Giacomin, M.A. Buitrago, and T. André for contributing to the manuscript; Mike Hopkins for all the support given to the first author while working at INPA; the herbaria that kindly gave us access to the specimens used in this research; and our colleagues from HSTM and INPA for the support and willingness to help.

\section{LITERATURE CITED}

Ahrends A, Rahbek C, Bulling MT, Burgess ND, Platts PJ, Lovett JC, Kindemba VW, Owen N, Sallu AN, Marshall AR, Mhoro BE, Fanning E, Marchant R (2011) Conservation and the botanist effect. Biol Conserv 144:131-140. doi: 10.1016/j.biocon.2010.08.008

Almeida TE (2014) Systematic studies in the genus Microgramma C.Presl (PolypodiaceaePolypodiopsida). Unpublished D. Phil. Thesis, Universidade Federal de Minas Gerais.

Atkinson MD, Jervis PA, Sangha SR (1997) Discrimination between Betula pendula, Betula pubescens, and their hybrids using near-infrared reflectance spectroscopy. Can J Forest Res 26:1896-1900. doi: 10.1139/x97-141

Berrueta LA, Alonso-Salces MR, Héberger K (2007) Supervised Pattern Recognition in Food Analysis. J Chromatogr A 1158(1-2):196-214. doi: 10.1016/j.chroma.2007.05.024

Burman P (1989) A comparative study of ordinary cross-validation, r-fold cross-validation and the repeated learning-testing methods. Biometrika 76(3):503-14. doi: 10.2307/2336116

Castillo R, Contreras D, Freer J, Ruiz J, Valenzuela S (2008) Supervised pattern recognition techniques for classification of Eucalyptus species from leaves NIR spectra. J Chil Chem Soc 53(4):1709-1713. doi: 10.4067/S0717-97072008000400016

Christenhusz MJM, Chase MW (2014) Trends and concepts in fern classification. Ann Bot 113:571-594. doi: 10.1093/aob/mct299

Costello MJ (2015) Biodiversity: The Known, Unknown, and Rates of Extinction. Current Biology 25(9):R368-R371. doi: 10.1016/j.cub.2015.03.051

Cui H-F, Ye Z-H, Xu L, Fu X-S, Fan C-W, Yu X-P (2012) Automatic and rapid discrimination of cotton genotypes by near-infrared spectroscopy and chemometrics. J Anal Methods Chem 2012:793468. doi: 10.1155/2012/793468

Damasco G, Daly DC, Vicentini A, Fine AVP (2019) Reestablishment of Protium cordatum (Burseraceae) based on integrative taxonomy. Taxon 68(1)34-46. doi: 10.1002/tax.12022

Durgante FM, Higuchi N, Almeida A, Vicentini A. 2013. Species spectral signature: discriminating closely related plant species in the Amazon with near-infrared leaf-spectroscopy. Forest Ecol Manag 291:240-248. doi: 10.1016/j.foreco.2012.10.045

Fan Q, Wang Y, Sun P, Liu S, Li Y (2010) Discrimination of Ephedra plants with diffuse 
bioRxiv preprint doi: https://doi.org/10.1101/2020.10.19.343947; this version posted October 19,2020 . The copyright holder for this preprint (which was not certified by peer review) is the author/funder, who has granted bioRxiv a license to display the preprint in perpetuity. It is made available under aCC-BY-NC-ND 4.0 International license.

Paiva et al. - Use of NIR on fern systematics

reflectance FT-NIRS and multivariate analysis. Talanta 80 (3):1245-1250. doi: 10.1016/j.talanta.2009.09.018

Fazekas JA, Kuzmina LM, Newmaster GS, Hollingsworth MP (2012) DNA barcoding methods for land plants. In: Kress WJ, Erickson, DL (eds) DNA Barcodes, Humana Press, Totowa, United States, pp 232-252. doi: 10.1007/978-1-61779-591-6_11.

Galtier N. 2018. Delineating species in the speciation continuum: A proposal. Evol Appl 12:12657-12663. doi: 10.1111/eva.12748

Gomes ACS, Andrade A, Barreto-Silva JS, Brenes-Arguedas T, Lopez DC, Freitas CC de, Lang C, Oliveira AA, Pérez AJ, Perez R, Silva JB, Silveira AMF, Vaz MC, Vendrami J, Vincentini A (2013) Local plant species delimitation in a highly diverse Amazonian forest: Do we all see the same species? J Veg Sci 2470-2479. doi: 10.1111/j.1654-1103.2012.01441.x

Guzmán Q, Antonio J (2020) Using visible-near-Infrared spectroscopy to classify Lichens at a neotropical dry forest. Ecol Indic 111:105999. doi: 10.1016/j.ecolind.2019.105999.

Hongyu G, Sandanielo MLV, Junior OJG (2016) Principal Component Analysis: theory, interpretations and applications. Eng Sci 1(5):83-90. doi: 10.18607/ES20165053.

Humphreys RJ, Reilly-Wapstra JM, Harbard JL, Davies NW, Griffin AR, Jordan GJ, Potts BM (2008) Discrimination between seedlings of Eucalyptus globulus, E. nitens and their F1 hybrid using near-infrared reflectance spectroscopy and foliar oil content. Silvae Genet 57(1-6):262269. doi: $10.1515 / \mathrm{sg}-2008-0040$

Kim SW, Ban SH, Chung H, Cho S, Chung HJ, Choi OS, Yoo OJ, Liu JR (2004) Taxonomic discrimination of flowering plants by multivariate analysis of Fourier Transform Infrared Spectroscopy data. Plant Cell Rep 23(4):246-250. doi: 10.1007/s00299-004-0811-1

Kohavi R (1995) A Study of CrossValidation and Bootstrap for Accuracy Estimation and Model Selection. International Joint Conference on Artificial Intelligence, pp 456-461.

Krajšek SS, Buh P, Zega A, Kreft S (2008) Identification of herbarium whole-leaf samples of Epilobium species by ATR-IR spectroscopy. Chem Biodivers 5(2):310-317. doi: 10.1002/cbdv.200890028

Lacerda AEB, Nimmo ER (2010) Can we really manage tropical forests without knowing the species within? Getting back to the basics of forest management through taxonomy. Forest Ecol Manag 259(5):995-1002. doi: 10.1016/j.foreco.2009.12.005

Lang C, Almeida DRA, Costa FRC (2017) Discrimination of taxonomic identity at species, genus and family levels using Fourier Transformed Near-Infrared Spectroscopy (FT-NIR). Forest Ecol Manag 406:219-227. doi: 10.1016/j.foreco.2017.09.003

Li F-W, Kuo, L-Y, Rothfels CJ, Ebihara A, Chiou, W-L, Windham MD, Pryer KM (2011) rbcL and matK earn two thumbs up as the core DNA barcode for ferns. PLoS One 6:e26597. doi: 10.1371/journal.pone.0026597

Li X, Yang Y, Henry RJ, Rossetto M, Wang Y, Chen S (2015) Plant DNA barcoding: from gene to genome. Biol Rev 90(1):157-166 .doi: 10.1111/brv.12104

Lima RAF de, Oliveira AA, Colletta GD, Flores TB, Coelho RLG, Dias P, Frey GP, Iribar A, Rodrigues RR, Souza VC, Chave J (2018) Can plant DNA barcoding be implemented in species-rich tropical regions? A perspective from São Paulo State, Brazil. Genet Mol Biol 41(3):661-670. doi: 10.1590/1678-4685-gmb-2017-0282

Mediavilla S, Escudero A (2009) Ontogenetic changes in leaf phenology of two co-occurring Mediterranean oaks differing in leaf life span. Ecol Res 24(5):1083-90. doi: 10.1007/s11284009-0587-4

Mediavilla S, Herranz M, González-Zurdo P, Escudero A (2014). Ontogenetic transition in leaf traits: a new cost associated with the increase in leaf longevity. J Plant Ecol 7(6):567-75. doi: 10.1093/jpe/rtt059

Mevik BH, Cederkvist RH (2004) Mean squared error of prediction (MSEP) estimates for principal component regression (PCR) and partial least squares regression (PLSR). J 
bioRxiv preprint doi: https://doi.org/10.1101/2020.10.19.343947; this version posted October 19, 2020. The copyright holder for this preprint (which was not certified by peer review) is the author/funder, who has granted bioRxiv a license to display the preprint in perpetuity. It is made available under aCC-BY-NC-ND 4.0 International license.

Paiva et al. - Use of NIR on fern systematics

15

Chemometr 18(9):422-429. doi: 10.1002/cem.887

Moran RC (2008) Diversity, biogeography, and floristics. In: Ranker TA, Haufler CH (eds) Biology and Evolution of Ferns and Lycophytes, Cambridge University Press, New York, pp 367-394. doi: 10.1017/CBO9780511541827.015

Ohira H, Koichi S, Tadaaki T, Shingo K, Hyeok-Jae C (2018) DNA Barcoding Suggested the Existence of Cryptic Species and High Biodiversity of South Korean Pseudoscorpions (Arachnida, Pseudoscorpiones). J Asia-Pac Biod 11(3):399-407. doi: 10.1016/j.japb.2018.04.005

Pérez-Losada M, Bloch R, Breinholt JW, Pfenninger M, Domínguez J (2012) Taxonomic assessment of Lumbricidae (Oligochaeta) earthworm genera using DNA barcodes. Eur J Soil Biol 48:41-47. doi: 10.1016/j.ejsobi.2011.10.003.

Pinheiro F, Dantas-Queiroz MV, Palma-Silva C (2018) Plant species complexes as models to understand speciation and evolution: a review of South American studies. CRC Cr Rev Plant Sci 37:54-80. doi: 10.1080/07352689.2018.1471565

Porco D, Bedos A, Greenslade P, Janion C, Skarzynski D, Stevens ID, van Vuuren J, Deharveng L (2012) Challenging species delimitation in Collembola: cryptic diversity among common springtails unveiled by DNA barcoding. Invertebr Syst 26(6):470-477. doi: 10.1071/IS12026

Prata EM, Sass C, Rodrigues DP, Domingos FM, Specht CD, Damasco G, Ribas CC, Fine PVA, Vincentini A (2018) Towards integrative taxonomy in Neotropical botany: disentangling the Pagamea guianensis species complex (Rubiaceae). Bot J Linn Soc 188:213-231. doi: 10.1093/botlinnean/boy051

Richard D, Evans D (2006) The need for plant taxonomy in setting priorities for designated areas and conservation management plans: a European perspective. In: Leadlay E, Jury S (eds) Taxonomy and Plant Conservation, Cambridge University Press, Cambridge, United Kingdom, pp 162-176.

R Core Team (2020) R: A language and environment for statistical computing http://www.Rproject.org/. R Foundation for Statistical Computing. Vienna, Austria.

Rodríguez-Fernández JI, Carvalho CJB de, Pasquini C, Lima KMG de, Moura MO, Arízaga GGC (2011) Barcoding without DNA? Species identification using near infrared spectroscopy. Zootaxa 2933(1):46-54. httt://doi.org/10.11646/zootaxa.2933.1.3

Salino A, Almeida TE, Smith AR, Gómez AN, Kreier, H-P, Schneider H (2008) A new species of Microgramma (Polypodiaceae) from Brazil and recircumscription of the genus based on phylogenetic evidence. Syst Bot 33(4):630-635. doi: 10.1600/036364408786500208

Schneider H, Schuettpelz E (2006) Identifying fern gametophytes using DNA Sequences. Mol Ecol Notes 6(4):989-991. doi: 10.1111/j.1471-8286.2006.01424.x

Schoute JC (1938) Morphology. In: Verdoon F (ed) Manual of Pteridology, Martinus Nijhoff, The Hague, Netherlands, pp 1-64.

Sharma A, Paliwal KK (2015) Linear discriminant analysis for the small sample size problem: an overview. Int J Mach Learn Cyb 6(3):443-454. doi: 10.1007/s13042-013-0226-9

Shen T, Hong Y, Wang ZY (2020) Discrimination of Gentiana and its related species using IR spectroscopy combined with feature selection and stacked generalization. Molecules 25(6):1442. doi: 10.3390/molecules25061442

Shokralla S, Gibson JF, Nikbakht H, Janzen DH, Hallwachs W, Hajibabaei M (2014) Nextgeneration DNA barcoding: using next-generation sequencing to enhance and accelerate DNA barcode capture from single specimens. Mol Ecol Resour 14892-901. doi: 10.1111/1755-0998. 12236

Smith JP Jr (2017) Dichotomous Keys - Their Structure and Use. Botanical Studies 58, Humboldt State University, Arcata, United States. http://digitalcommons.humboldt.edu/botany_jps/58. Accessed 16 October 2020.

Sota ER de la (1973) A new species of Microgramma from Argentina. Am Fern J 63(3):61-64. 
bioRxiv preprint doi: https://doi.org/10.1101/2020.10.19.343947; this version posted October 19, 2020. The copyright holder for this preprint (which was not certified by peer review) is the author/funder, who has granted bioRxiv a license to display the preprint in perpetuity. It is made available under aCC-BY-NC-ND 4.0 International license.

Paiva et al. - Use of NIR on fern systematics

https://www.jstor.org/stable/1546180

Stein ED, Martinez MC, Stiles S (2014) Is DNA barcoding actually cheaper and faster than traditional morphological methods: results from a survey of freshwater bioassessment efforts in the United States? PLoS ONE 9:e95525. doi: 10.1371/journal.pone.0095525

Stuart BH (2005) Infrared Spectroscopy: Fundamentals and Applications. John Wiley \& Sons, Chichester, England.

Vere N, Rich TCG, Ford CR, Trinder SA, Long C, Moore CW, Satterthwaite D, Davies H, Allainguillaume J, Ronca S, Tatarinova T, Garbett H, Walker K, Wilkinson MJ (2012) DNA barcoding the native flowering plants and conifers of Wales. PLoS ONE. 7(6):e37945. doi: 10.1371/journal.pone.0037945

Wagner WH, Wagner FS (1977) Fertile-sterile leaf dimorphy in ferns. Gard Bull (Singapore) 30:251-267.

Wang HH, Lu MJ, Wen J, Ebihara A, Li D (2016) Applying DNA Barcodes to identify closely related species of ferns: a case study of the chinese Adiantum (Pteridaceae). PLoS ONE 11(9):e0160611. doi: 10.1371/journal.pone.0160611

Workman J, Weyer L (2007) Practical Guide to Interpretive Near-Infrared Spectroscopy. CRC Press, Boca Raton, United States.

Yadav S, Shukla S (2016) Analysis of k-Fold Cross-Validation over Hold-Out Validation on Colossal Datasets for Quality Classification, 78-83. In Advanced Computing (IACC), IEEE 6th International Conference on IEEE. doi: 10.1109/IACC.2016.25

\section{APPENDIX}

Specimens used for spectral data capture. Herbaria acronym (in parentheses) follow Thiers (2020 onwards: http://sweetgum.nybg.org/science/ih/).

\begin{tabular}{lll}
\hline Taxon & Country & Voucher \\
\hline Microgramma crispata & Brazil & Almeida 4430 (HSTM) \\
Microgramma crispata & Brazil & Souza 1565 (BHCB) \\
Microgramma crispata & Brazil & Krieger 10715 (BHCB) \\
Microgramma crispata & Brazil & Lima 126 (HSTM) \\
Microgramma crispata & Brazil & Salino 13919 (HSTM) \\
Microgramma crispata & Brazil & Dittrich 2187 (HSTM) \\
Microgramma lycopodioides & Brazil & Suemitsu 522 (HSTM) \\
Microgramma lycopodioides & Brazil & Almeida 4222 (HSTM) \\
Microgramma lycopodioides & Brazil & Giacomin 2577 (HSTM) \\
Microgramma lycopodioides & Brazil & Giacomin 1791 (HSTM) \\
Microgramma lycopodioides & Panama & Salino 15437 (BHCB) \\
Microgramma lycopodioides & Brazil & Viana 3386 (BHCB) \\
Microgramma lycopodioides & Bolivia & Almeida 3130(BHCB) \\
Microgramma lycopodioides & Brazil & Salino 10067 (BHCB) \\
Microgramma lycopodioides & Brazil & Giacomin 2002 (HSTM)
\end{tabular}




\begin{tabular}{|c|c|c|}
\hline Microgramma lycopodioides & Brazil & Giacomin 1933 (BHCB) \\
\hline Microgramma dictyophylla & Brazil & Almeida 2605 (BHCB) \\
\hline Microgramma dictyophylla & Brazil & Vidal 739 (BHCB) \\
\hline Microgramma dictyophylla & Brazil & Almeida 2230 (HSTM) \\
\hline Microgramma dictyophylla & Brazil & Almeida 2588 (HSTM) \\
\hline Microgramma dictyophylla & Brazil & Freitas 33 (INPA) \\
\hline Microgramma persicariifolia & Brazil & Almeida 2738 (HSTM) \\
\hline Microgramma persicariifolia & Brazil & Mota 2411 (BHCB) \\
\hline Microgramma persicariifolia & Brazil & Almeida 2203 (BHCB) \\
\hline Microgramma persicariifolia & Brazil & Salino 304 (BHCB) \\
\hline Microgramma persicariifolia & Brazil & Suemitsu 500 (HSTM) \\
\hline Microgramma thurnii & Brazil & Almeida 2563 (HSTM) \\
\hline Microgramma thurnii & Brazil & Almeida 2587 (BHCB) \\
\hline Microgramma thurnii & Brazil & Araújo 115 (INPA) \\
\hline Microgramma thurnii & Brazil & Acevedo 8152 (INPA) \\
\hline Microgramma thurnii & Brazil & Almeida 3757 (INPA) \\
\hline Microgramma vacciniifolia & Brazil & Souza 1565 (BHCB) \\
\hline Microgramma vacciniifolia & Brazil & Almeida 2314 (HSTM) \\
\hline Microgramma vacciniifolia & Brazil & Salino 6573 (HSTM) \\
\hline Microgramma vacciniifolia & Brazil & Giacomin 1707 (HSTM) \\
\hline Microgramma vacciniifolia & Brazil & Salino 8166 (HSTM) \\
\hline Microgramma vacciniifolia & Brazil & Salino 14386 (HSTM) \\
\hline Microgramma vacciniifolia & Brazil & Salino 5380 (HSTM) \\
\hline Microgramma vacciniifolia & Brazil & Salino 1800 (HSTM) \\
\hline Microgramma vacciniifolia & Brazil & Almeida 4802 (HSTM) \\
\hline Microgramma vacciniifolia & Brazil & Salino 6116 (HSTM) \\
\hline Microgramma baldwinii & Brazil & Almeida 4596 (HSTM) \\
\hline Microgramma baldwinii & Brazil & Ribeiro 2728 (INPA) \\
\hline Microgramma baldwinii & Brazil & Vieira 937 (INPA) \\
\hline Microgramma baldwinii & Brazil & Poole 1645 (INPA) \\
\hline Microgramma baldwinii & Brazil & Nelson 304 (INPA) \\
\hline Microgramma baldwinii & Brazil & Freitas 602 (INPA) \\
\hline Microgramma baldwinii & Brazil & Nee 46235 (INPA) \\
\hline Microgramma squamulosa & Brazil & Giacomin 1655 (HSTM) \\
\hline Microgramma squamulosa & Bolivia & Almeida 3105 (BHCB) \\
\hline Microgramma squamulosa & Brazil & Almeida 3175 (HSTM) \\
\hline
\end{tabular}




\begin{tabular}{|c|c|c|}
\hline Microgramma squamulosa & Brazil & Almeida 3363 (HSTM) \\
\hline Microgramma squamulosa & Brazil & Almeida 2310 (HSTM) \\
\hline Microgramma squamulosa & Brazil & Lima 65 (HSTM) \\
\hline Microgramma squamulosa & Brazil & Dittrich 1655 (HSTM) \\
\hline Microgramma squamulosa & Brazil & Almeida 4878 (HSTM) \\
\hline Microgramma geminata & Brazil & Salino 10900 (HSTM) \\
\hline Microgramma geminata & Brazil & Salino 14326 (HSTM) \\
\hline Microgramma geminata & Brazil & Salino 2313 (HSTM) \\
\hline Microgramma geminata & Brazil & Almeida 3071 (HSTM) \\
\hline Microgramma geminata & Brazil & Salino 8208 (HSTM) \\
\hline Microgramma geminata & Brazil & Salino 6679 (HSTM) \\
\hline Microgramma geminata & Brazil & Salino 6574 (HSTM) \\
\hline Microgramma geminata & Brazil & Salino 2560 (HSTM) \\
\hline Microgramma geminata & Brazil & Salino 1655 (HSTM) \\
\hline Microgramma lindbergii & Brazil & Almeida 3068 (HSTM) \\
\hline Microgramma lindbergii & Brazil & Almeida 228 (HSTM) \\
\hline Microgramma lindbergii & Brazil & Salino 4449 (HSTM) \\
\hline Microgramma lindbergii & Brazil & Salino 3760 (HSTM) \\
\hline Microgramma lindbergii & Brazil & Salino 929 (HSTM) \\
\hline Microgramma lindbergii & Brazil & Echternacht 238 (HSTM) \\
\hline Microgramma percussa & Brazil & Albuquerque 198 (INPA) \\
\hline Microgramma percussa & Brazil & Albuquerque 281 (INPA) \\
\hline Microgramma percussa & Brazil & Coelho 88 (INPA) \\
\hline Microgramma percussa & Brazil & Albuquerque 717 (INPA) \\
\hline Microgramma percussa & Brazil & Madison 618 (INPA) \\
\hline Microgramma percussa & Brazil & Maia 58 (INPA) \\
\hline Microgramma percussa & Brazil & Amaral 317 (INPA) \\
\hline Microgramma percussa & Brazil & Ferreira 3498 (INPA) \\
\hline Microgramma percussa & Brazil & Quaresma 9 (INPA) \\
\hline Microgramma megalophylla & Brazil & Rodrigues 2554 (INPA) \\
\hline Microgramma megalophylla & Brazil & Rodrigues 8840 (INPA) \\
\hline Microgramma megalophylla & Brazil & Silva 105 (INPA) \\
\hline Microgramma megalophylla & Brazil & Silva 1637 (INPA) \\
\hline Microgramma megalophylla & Brazil & Albuquerque 1041 (INPA) \\
\hline Microgramma megalophylla & Brazil & Coelho 41 (INPA) \\
\hline Microgramma megalophylla & Brazil & Madison 190 (INPA) \\
\hline
\end{tabular}




$\begin{array}{lll}\text { Microgramma megalophylla } & \text { Brazil } & \text { Amaral 500 (INPA) } \\ \text { Microgramma reptans } & \text { Brazil } & \text { Almeida 2630 (HSTM) } \\ \text { Microgramma reptans } & \text { Brazil } & \text { Costa 4 (HSTM) } \\ \text { Microgramma reptans } & \text { Brazil } & \text { Almeida 2185 (HSTM) } \\ \text { Microgramma reptans } & \text { Brazil } & \text { Silva 35 (HSTM) } \\ \text { Microgramma reptans } & \text { Brazil } & \text { Giacomin 2576(HSTM) } \\ \text { Microgramma reptans } & \text { Brazil } & \text { Fraga 3990 (INPA) } \\ \text { Microgramma reptans } & \text { Brazil } & \text { Madison 44 (INPA) } \\ \text { Microgramma reptans } & \text { Brazil } & \text { Madison 412 (INPA) } \\ \text { Microgramma reptans } & \text { Brazil } & \text { Freitas 590 (INPA) } \\ \text { Microgramma reptans } & \text { Brazil } & \text { Freitas 650 (INPA) } \\ \text { Microgramma reptans } & \text { Brazil } & \text { Mota 2413 (INPA) } \\ \text { Microgramma reptans } & \text { Brazil } & \text { Almeida 3596 (INPA) }\end{array}$

